ORIENTAL JOURNAL OF CHEMISTRY

An International Open Access, Peer Reviewed Research Journal

www.orientjchem.org
ISSN: 0970-020 X

CODEN: OJCHEG

2020, Vol. 36, No.(4):

Pg. 621-631

\title{
Novel Coronavirus (Covid-19): A Review on Epidemiology, Pathophysiology, Molecular Mechanism, Therapeutic Evidence and Preventive Measures
}

\author{
KUMARAN SUBRAMANIAN ${ }^{1}$, ANAHAS PERIANAIKA MATHARASI ANTONYRAJ ${ }^{2}$, \\ PRASANNABALAJI NAINANGU ${ }^{3 *}$, PUGAZHVENDAN SAMPATH RENUKA ${ }^{4}$, RAJASEKAR \\ THIRUNAVUKARASU ${ }^{1}$, SADAIAPPAN BALAMURUGAN ${ }^{5}$, BHARATHI SELVARAJ ${ }^{3}$, \\ SURESH GOPAL ${ }^{3}$, GURU PRASAD SRINIVASAN ${ }^{6}$, PRAVEEN KUMAR ELANGO ${ }^{3}$, \\ BALASUBRAMANIYAN BALAKRISHNAN ${ }^{7}$ and WILSON ARUNI. A8,9,10
}

${ }^{1}$ Centre for Drug Discovery and Development, Sathyabama Institute of Science and Technology, Chennai, Tamil Nadu, India.

²Department of Microbiology, Centre of Excellence in Life Sciences, Bharathidasan University, Palkalaiperur, Tiruchirappalli 620 024, Tamilnadu, India.

3Department of Microbiology, Sri Sankara Arts and Science College, Kanchipuram-631561, Tamil Nadu, India.

${ }^{4}$ Department of Zoology-Aringar Anna Government Arts College, Cheyyar, Tamil Nadu, India.

${ }^{5}$ Plankton Ecology laboratory, CSIR- National Institute of Oceanography, Goa-403004, India. ${ }^{6} \mathrm{CAS}$ in Marine Biology, Parangipettai, Tamil Nadu, India.

${ }^{7}$ Department of Zoology, Government Arts College, C.Mutlur, Chidambaram, Tamil Nadu, India.

${ }^{8}$ Department of Biotechnology, School of Bio and Chemical Engineering, Sathyabama Institute of Science and Technology, Chennai-600119, Tamil Nadu, India.

${ }^{9}$ School of Medicine, Loma Linda University, CA, USA.

10US Department of Veteran affairs, Loma Linda, CA, USA

${ }^{\star}$ Corresponding author E-mail: applenpb @gmail.com

http://dx.doi.org/10.13005/ojc/360405

(Received: June 04, 2020; Accepted: July 12, 2020)

\begin{abstract}
Currently, the deadly epidemic COVID-19 was exponentially spread across the world as a pandemic outbreak caused by a novel coronavirus, termed as SARS-CoV-2 (Severe acute respiratory syndrome coronavirus 2). In this view, the imminent danger of a pandemic situation surge the researchers and physicians to understand the molecular mechanism and pathology of this novel virus, in order to discover promising therapeutic drugs and vaccines to cure the diseases. At present, World Health Organization (WHO) updates on 27th June, 2020 for coronavirus disease (COVID-19) outbreak situation with confirmed cases of 9,653,048 and 491,128 deaths in 211 countries, areas or territories. To control the global outbreak, robust measures have been implemented across the world to minimize COVID-19 disease spread, in specific restricting international and domestic flights, enforcing lockdowns in susceptible areas, social distancing, etc. Although, a very few broad-spectrum antiviral drugs was tested in clinical trials against COVID-19 virus, which resulted in patient recovery. Based on existing published data, this review extensively highlights the COVID-19 epidemiology, clinical manifestations, prognosis, treatment and prevention. In order to offer a detailed overview to public health officials and future readers all over the world, we explain the latest interpretation of COVID-19 and presented the current state of implementation of the medical intervention in this review. This review is hoped to help the public understand and combat with SARS-CoV-2, as well as provide a guideline for future research.
\end{abstract}

Keywords: COVID-19, Epidemiology, Pathogenesis, SARS-CoV-2, CRISPR/Cas13 System.

This is an Open Access article licensed under a Creative Commons license: Attribution 4.0 International (CC- BY). Published by Oriental Scientific Publishing Company @ 2018 


\section{INTRODUCTION}

At the end of the December 2019, an occurrence of unspecified pneumonia was documented in Wuhan, Province of Hubei, People's Republic of China. The clinical properties were also identical to viral pneumonia. After evaluating respiratory specimens, specialists at the Chinese government disease control and prevention reported that a novel coronavirus induced pneumonia, then identified as the novel coronavirus pneumonia ${ }^{1}$. The WHO has provisionally termed the disease as 'COVID-19'. The International Committee on Taxonomy of Viruses designated the virus Coronavirus-2 (SARS-CoV-2) as a severe acute respiratory syndrome on $11^{\text {th }}$ February $2020^{2}$. And WHO declared the SARS-CoV-2 outbreak as coronavirus disease 2019 (COVID-19) ${ }^{3}$.

The coronaviruses were belongs to the largest group of nidovirales, includes the family coronaviridae, roniviridae and arteriviridae. Coronavirinae is one of two subfamilies in coronaviridae family, the other belongs to the family torovirinae. Further, the coronavirinae are subdivided into four group's namely alpha, beta, gamma and delta coronaviruses. Based on serology, the viruses were primarily categorized into these groups and now sorted by phylogenetic clustering.

The coronaviruses are smallest particle size of $65 \mathrm{~nm}$ and possess positive sense single-strand, RNA genome varying from 26 to $32 \mathrm{~kb}$ (kilo bases) in length. Coronavirus was sub-grouped as alpha $(\alpha)$, beta $(\beta)$, gamma $(\lambda)$ and delta $(\delta)$ coronavirus. The acute lung injury (ALI) leads to pulmonary failure and fatality in humans were caused by severe acute respiratory syndrome coronavirus (SARS-CoV), avian influenza $A$ virus (H5N1), influenza virus $A$ 2009 (H1N1) and Middle East respiratory syndrome coronavirus (MERS-CoV).

In 2002, the coronaviruses were believed to infect only animals, until the world experienced an outbreak of severe acute respiratory syndrome (SARS) caused by SARS-CoV in Guangdong, China ${ }^{4}$.

Presently, there are numerous researches on SARS-CoV-2 and COVID-19. This review provides a comprehensive overview on this viral infection, includes epidemiology, genome structure and organization, CRISPR/Cas 13 system, pathophysiology, laboratory diagnosis, antiviral therapy, treatment and prevention of SARS-CoV-2. Our research would offer adequate information to understand this SARS-CoV-2 virus, and further scientific studies were needed to reduce disease outbreaks and to develop vaccines and new drugs.

\section{Epidemiology}

Since 31 December 2019 and as of 26 June 2020, 9581803 cases of COVID-19 in accordance with the applied case definitions and testing strategies in the affected countries have been reported, including 489182 deaths. Data provided by the WHO Health Emergency Dashboard report 9,653,048 confirmed cases of COVID-19, including 491, 128 deaths (as of 8:18am CEST, 27 June 2020). To date, there are cases in 215 Countries. Considering case comparison, in Americas there are 4, 816, 794 confirmed cases; Europe 2, 638, 903; Eastern Mediterranean 1, 006, 279; Western Pacific 211, 774; South-East Asia 710, 455; Africa 268, 102. The highest fatal cases have been recorded in the US $(124,161)$ followed by Brazil $(54,971)$, UK $(43,414)$, Italy $(34,708)$, France $(29,700)$, Spain $(28,338)$, Mexico $(25,060)$, India $(15,686)$ and other countries (Table1) ${ }^{5}$.

The $\mathrm{WHO}^{5}$, dated on $11^{\text {th }}$ February 2020 , as of $10^{\text {th }}$ March 2020, 113, 702 confirmed cases were reported global and 4012 deaths have been confirmed; $71 \%$ of all showed cases $(80,924)$ and $78 \%$ of all COVID-19 (3140)-associated deaths are from China and its territories. Since the first detected case in Wuhan, 109 different nations have reported as a minimum one confirmed case of COVID-19. The WHO formally recognized China as a "very high chance" place for COVID-19.

Lu et al., ${ }^{6}$ reported that some coronaviruses (CoVs) were originally transmitted through enzootic pathogens, confined only to their natural animal hosts, but crossed the barrier between animal and human species and progressed to human zoonotic diseases. As a result, these cross-species transmission allowed coronaviruses (CoVs) such as acute respiratory syndrome coronavirus (SARS-CoV) and, Middle Eastern respiratory syndrome (MERS-CoV) jumped from avian, animal to human to develop a virulent strain. The consecutive outbreak of SARS in 2003 resulted in a pandemic situation with 8096 confirmed cases and 774 mortality cases reported worldwide resulting in a death rate of 9.6 percent ${ }^{7}$. 
Table 1: Global epidemiological forecasts of coronaviruses outbreak in several countries (data from the Official World Health Organisation) ${ }^{5}$

\begin{tabular}{|c|c|c|c|}
\hline S.No & Country & otal Confirmed Cases & Total Death \\
\hline 1 & Australia & 7,595 & 104 \\
\hline 2 & Brazil & $1,228,114$ & 54,971 \\
\hline 3 & Cameroon & 12,592 & 313 \\
\hline 4 & Chile & 263,360 & 5,068 \\
\hline 5 & China & 85,172 & 4,648 \\
\hline 6 & Denmark & 12,675 & 604 \\
\hline 7 & Egypt & 62,755 & 2,620 \\
\hline 8 & Finland & 7,191 & 328 \\
\hline 9 & French Polynesia & 60 & 0 \\
\hline 10 & Germany & 193,243 & 8,954 \\
\hline 11 & Ghana & 15,834 & 103 \\
\hline 12 & Guam & 240 & 5 \\
\hline 13 & India & 508,953 & 15,685 \\
\hline 14 & Iran & 217,724 & 10,239 \\
\hline 15 & Italy & 239,961 & 34,708 \\
\hline 16 & Japan & 18,297 & 971 \\
\hline 17 & Mexico & 202,951 & 25,060 \\
\hline 18 & Netherlands & 50,005 & 6,103 \\
\hline 19 & New Zealand & 1,172 & 22 \\
\hline 20 & Nigeria & 23,298 & 554 \\
\hline 21 & Northern Mariana Islands & 30 & 2 \\
\hline 22 & Pakistan & 198,883 & 4,035 \\
\hline 23 & Peru & 268,602 & 8,761 \\
\hline 24 & Republic of Korea & 12,653 & 282 \\
\hline 25 & Russia & 627,646 & 8,969 \\
\hline 26 & Saudi Arabia & 174,577 & 1,474 \\
\hline 27 & South Africa & 124,590 & 2,340 \\
\hline 28 & Spain & 247,905 & 28,338 \\
\hline 29 & Sweden & 65,137 & 5,280 \\
\hline 30 & Turkey & 194,511 & 5,065 \\
\hline 31 & United Kingdom & 309,364 & 43,414 \\
\hline 32 & United States & $2,407,590$ & 124,161 \\
\hline
\end{tabular}

During the period of April 2012 to October 2018, about 2229 laboratory confirmed cases have been reported globally, since the Middle Eastern respiratory syndrome (MERS-CoV) outbreak including 791 deaths with a case fatality rate of 35.5 percent ${ }^{8}$. COVID-19 began emerging at several local hospitals in Wuhan, Hubei Province, China at the end of December 2019. Clinicians have diagnosed this illness as a virus induced pneumonia, based on clinical symptoms, $\mathrm{X}$-rays and serological diagnosis. Initial epidemiological investigations indicated that the majority of reported cases were related to their exposure in local Huanan seafood wholesale market in Wuhan, China. Apart from seafoods, several types of live wild animals were available in this market for trade throughout the year until it was enforced to shutdown the market on January $1^{\text {st }} 2020$.
As anticipated, the Chinese Center for Disease Control and Prevention (CDC) has isolated SARS-CoV-2 from the Huanan seafood marketplace in environmental samples, which turned into answerable for the origin of outbreak. Hung and his coworker ${ }^{9}$ reported of these decisive end become disputed because cases did not linked to the marketplace. Further, it also changed to the location that at least two cases with one of a kind SARS-CoV-2 had occurred a few months before COVID-19 was formally reported by Xiong et al., ${ }^{10}$.

Recently, $\mathrm{Yu}^{11}$ and his group reported the latest phyloepidemiological evaluation reveals that SARS-CoV-2 might have been imported from different places at the Huanan seafood marketplace. Till date, it remains conflict with the first outbreak of SARS-CoV-2 because the epidemiological and etiological researches are being conducted through the Chinese language health government.

Transmission of Covid-19.

Individuals will get COVID-19 infection from other individuals who harbor the virus and it can transmit from one person to another through droplets or droplet nuclei from nose or mouth through coughs or sneezing. Such droplets are landed on fomites and surfaces around the human. Several persons will acquire the COVID-19 infection through touching the contaminated objects or surfaces and subsequently rubbing their eyes, nose and mouth. Individuals may also acquire the infection, if they breathe the droplets carrying viral particles which expelled from COVID-19 infected person. Hence, it remains vital to stay more than 1 meter away from a sick person. The $\mathrm{WHO}$ is reviewing ongoing research on distribution of COVID-19 and will continue the investigation until the end of $2020^{4}$.

\section{Genomic organization}

As described earlier, coronaviruses are enveloped linear, non-segmented, positive-sense, single-stranded RNA genome of about $27-32 \mathrm{~kb}$. The viral genome contains a cap structure at $5^{\prime}$ end and poly (A) tail sequence $3^{\prime}$ terminal end which allows it to act as an mRNA for the translation of replicase polyproteins. About two-thirds of viral genome $(20 \mathrm{~kb})$ was occupied by replicase gene encoding the nonstructural proteins (nsps), as divergent to the structural and accessory proteins, which form only $10 \mathrm{~kb}$ of the viral genome. It has been well documented 
that viral genome contains a transcription regulating leader sequence (TRS), $5^{\prime}$ untranslated region ( $5^{\prime}$ UTR) and $3^{\prime}$ untranslated region ( $3^{\prime}$ UTR) with several stem loop structures required to replicate and transcribe RNA.

In addition, transcriptional regulatory sequences (TRSs) are required for expression of structural or accessory genes at the beginning of these genes. The $3^{\prime}$ untranslated region ( $3^{\prime}$ UTR) also contains the RNA structures necessary for the replication and synthesis of viral RNA. The coronavirus genome structure contain $5^{\prime}$-leader-UTRreplicase-spike (S)-envelope (E)-membrane (M)nucleocapsid (N)-3'UTR poly (A) tail, with accessory genes interspersed at the $3^{\prime}$ end of the structural genes inside the cell. The accessory proteins are almost entirely less important for replication in tissue culture; however, several studies have been shown to have important roles in viral pathogenesis ${ }^{12}$.

\section{Pathophysiology}

The mechanisms of coronavirus (CoV) pathophysiology and its virulence linked with the functions of nsps and structural proteins of SARS$\mathrm{CoV}-2^{13}$. Coronaviruses (CoVs) are enveloped with nucleocapsid, positive-stranded RNA viruses. Considerations of viral structure and genome are inevitable to understand the pathogenetic mechanisms of SARS-CoV-2. The single stranded RNA genomic structure of CoVs is organized about $30 \mathrm{~kb}$ in size, being the largest well- known RNA viruses with a $5^{\prime}$ end cap structure and $3^{\prime}$ terminal poly-A tail. The synthesis of polyprotein (pp) $1 \mathrm{a}$ and $1 \mathrm{ab}$ from viral RNA is recognized in the host. The transcription process takes place in replication-transcription complex (RTC) arranged in double-membrane vesicles and transcribe through subgenomic RNAs (sgRNAs) sequences. Specific structural and accessory proteins transcribed by specialized sgRNAs are evident in diverse CoVs ${ }^{14}$.

Notably, termination process takes place in transcription regulatory sequences which situated between the open reading frames (ORFs) and act as template for subgenomic RNAs synthesis. At least six ORFs may be present in the atypical CoV genome. A frameshift between open reading frames (ORFs) $1 \mathrm{a}$ and $1 \mathrm{~b}$ facilitates the development of polypeptides (pp) 1a and 1ab that are processed with viral gene encodes chymotrypsin like protease or main protease and papain like proteases to synthesize 16 non-structural proteins. Other ORFs encode for structural protein contain nucleocapsid proteins, membrane and spike proteins along with some accessory proteins ${ }^{14}$.

\section{Evolutionary Perspectives of SARS-CoV-2}

Bats are vectors of a variety of pathogens to cause disease, which are known to infect both domestic animals and humans. Human behaviors that increase exposure to bats will likely to increase the risk of infectious diseases and transmit from bats to humans in the future. Bats were established as the possible reservoir for coronavirus ( $\mathrm{CoV}$ ) with severe acute respiratory syndrome (SARS) ${ }^{15}$. While bat is documented as a reservoir for SARS-like CoVs, it cannot infect human beings directly, unless they are mutated or undergo recombination in host animals ${ }^{16}$. For example, animal hosts SARS-CoV (severe acute respiratory syndrome) pandemic in 2003, transmit from bats to palm civet and subsequently transmitted to humans. Similarly, MERS-CoV (Middle East respiratory syndrome) in 2012, transmit from bats to dromedary camel, before infecting humans. With regard to the SARS-CoV-2 intermediate animal host, it has been reported that the $99 \%$ sequence similarity between pangolin origin $\mathrm{CoV}$ s and human infecting SARS-CoV-2, signifying that SARS-CoV-2 could be of pangolin origin ${ }^{17}$.

Several Chinese studies track other possible SARS-CoV-2 animal hosts, which are of great importance for COVID-19 prevention and control.

\section{Clinical manifestations}

The clinical characteristics of patients diagnosed with SARS-CoV-2 varied from moderate, non specific indications to acute pneumonia with impairment to the organ function. The major specific signs included fever (77.4-98.6\%), coughing (59.4-81.8\%), nausea (38.1-69.6\%), shortness of breath (3.2-55.0\%), muscle weakness (11.1-34.8\%), sputum development (28.2-56.5\%), and headache (6.5-33.9\%)18-22. The minor symptoms were sore throats, runny nose, chest pain, hemoptysis, conjunctival inflammation, diarrhea, nausea and vomiting ${ }^{18-22}$. However, one study found that 39.6 percent of 140 diagnosed COVID-19 patients had gastro-intestinal symptoms ${ }^{23}$ and another study Wang ${ }^{20}$ also found that 10.1 percent of patients had abdominal pain at the onset of infections. After 
hospitalization, several patients didn't progressed often have onset fever ${ }^{22}$, and even some critical patients also didn't even have fever. An infection with SARS-CoV-2, SARS-CoV and MERS-CoV exhibits several common clinical symptoms includes fever, cough, muscle aches, and shortness of breath ${ }^{24}$. Moreover, patients infected with SARS and MERS have higher almost one-third of gastro-intestinal intervention than patients infected with COVID1925. MERS has a significantly increased risk of renal dysfunction, common distinctive feature not often observed in other infections with human coronavirus $^{26,27}$. Recently, Chen et al., ${ }^{19}$ found that out of 249 patients tested, 90 patients $(36.1 \%)$ had one or more chronic health conditions that coexisted. Most common comorbidities were cardiovascular and cerebrovascular diseases observed in 55 patients $(21.7 \%)$, preceded by endocrine-system diseases in 25 patients (10.0\%) and other patients have less common symptoms.

\section{Detection and Diagnosis}

WHO suggested to collect specimens such as sputum expectorate, bronchial aspirate, transthoracic aspirate, endotracheal tube speciemens and bronchoalveolar lavage from both the lower and the upper respiratory tract (throat specimens, nasopharyngeal swabs and nasal discharges) from infected patients. The analysis of bronchoalveolar lavage (BAL) samples should be performed only in manually ventilated patients, because lower samples of the respiratory tract appear to be positive for a longer duration. Samples should be held at $4^{\circ} \mathrm{C}$. At present, RT-PCR analysis for COVID-19 commonly use samples collected from the upper respiratory tract using swabs for laboratory diagnosis. RT-PCR amplifies a small quantity of viral genetic material in a specimen which involves the synthesis of a double-stranded DNA molecule from the RNA mold. Reverse polymerase chain reaction (RT-PCR) is generally considered as gold standard method for SARS-CoV-2 virus identification.

Depends upon the availability of genetic material, analysis was performed for certain retained parts of the CoV genetic code. The Shanghai public health clinical center and school of public health at Fudan University, Shanghai, China on virological organization identified probes based on the initial gene sequence and further confirmation by other laboratories. If the diagnostic test result becomes positive it is recommended to repeat the test for further confirmation through molecular diagnostic methods. If the patients have been confirmed for COVID-19 diagnosis, the laboratory examination should be validated thoroughly in order to determine the viral clearance before discharge from observation.

At present, laboratory diagnosis depends primarily on quantitative reverse transcriptase polymerase chain reactions for the detection of SARS-CoV-2 nucleic acid for effective virus isolation and genome sequencing of SARS-CoV-2. The novel coronavirus (CoV) detected in respiratory or blood samples is closely similar to the known SARSCoV-2 coronavirus, it could be used as a prognostic guide for SARS-CoV-2 infection. Currently, antibody detection reagents for immunoglobulin IgM, IgG and antigen detection reagents for SARS-CoV-2 have also been developed by using colloidal gold and enzyme-linked immunosorbent technologies ${ }^{28}$.

\section{Antiviral therapy}

Currently, there are no anti-SARS-CoV-2 drugs and vaccines were available in the treatment centers. The most effective strategy for the production is 'existing drug, Revamped use.' Remdesivir (GS5734) is a broad spectrum drug developed by Gilead Sciences pharmaceutical companies in United States, it is a nucleoside derivative synthetic drug that can suppress Ebola virus and thus act as an antiviral agent. In vitro and In vivo studies indicated that a low dose of remdesivir possess strong inhibitory effect on SARS-CoV and MERS-CoV ${ }^{29}$.

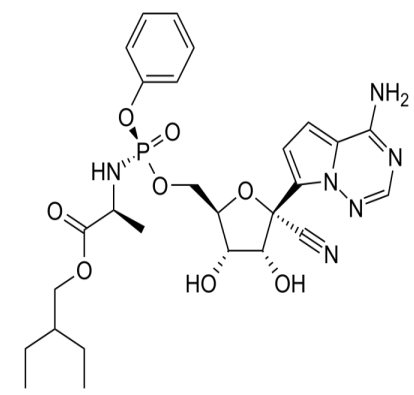

Fig. 1. Chemical structure of nucleotide adenosine analogue Remdesivir antiviral drug ${ }^{30}$

Remdesivir (GS-5734), a phosphoramidate prodrug of Pyrrolo[2,1-f][triazin-4-amino] adenine C-nucleoside possessing broad spectrum activity of antiviral property (Fig. 1). Remdesivir is a prodrug 
of adenosine analog metabolized into GS-441524 (active form), which interacts with RNA dependent viral RNA polymerase, thus evading viral exonuclease proofreading and blocking RNA synthesis. It exhibited a strong inhibitory effect against RNA dependent viral RNA polymerase with unaffected proof reading and low sensitivity to target genetic changes ${ }^{31}$.

Presently, a phase III scientific trial of radcivir for the treatment of COVID-19 changed into formally released at Wuhan Jinyintan clinic on $5^{\text {th }}$ February 2020 under the management of China, Japan friendship health center, and its efficacy may be evaluated the use of strict dual-blind clinical approval. Recently, In vitro studies demonstrated strong inhibitory activity of radcivir and chloroquine on SARS-CoV-216. In addition, alpha interferon inhalation, ralproveravir, ritonavir and intravenous ribavirin (Fig. 2) injection can also be prescribed by the National Health Commission (2020), step in with the radical coronavirus pneumonia analysis and treatment strategy (Trial version 6) ${ }^{32}$.<smiles>NC(=O)c1ncn([C@@H]2O[C@H](CO)[C@@H](O)[C@H]2O)n1</smiles>

Fig. 2. Chemical structure of Ribavirin antiviral drug ${ }^{33}$

\section{Nucleic acid detection}

Viral diagnosis is a critical aspect of COVID19 arsenal. After the initial outbreak, laboratory based diagnostic methods were used to detect the viral genome sequence through RT-PCR or next generation sequencing technologies became rapidly accessible. Subsequently, a number of biotechnology companies rapidly developed nucleic acid detection kits, sequencing systems and several fluorescent quantitative kits have been ratified expeditiously by the China Food and Drug Administration (CFDA) ${ }^{34}$.

\section{CRISPR/Cas13 System}

If the patient samples contain low viral load concentrations as 1 copy per microliter, the Cas13-based SHERLOCK (specific high-sensitivity enzymatic reporter unlocking) system was widely used to identify zika virus (ZIKV) and dengue virus $(\mathrm{DENV})^{35}$. Previously, Zhang et al., ${ }^{36}$ reported that CRISPR/Cas13-based SHERLOCK techniques were used to identify SARS-CoV-2. Though, the CRISPR/ Cas 13 system yet to be checked as it was not validated on COVID-19 patients clinical samples.

\section{Current scenario}

Animal models play a vital role in identifying pathways of viral pathogenicity from entry to transmission and to develop targeted therapies. Subsequently, several animal models were used to investigate the replication of SARS-CoV that exhibited signs of serious infection37. When compared to SARS-CoV, pathogenesis of MERSCoV has not been detected in small laboratory animals (mice and hamster).

Mice are not prone to MERS-coronavirus infection due to the non-compatibility of the DPP4 receptor ${ }^{38}$. The complete genome of novel coronavirus (COVID 19) is extra than 80 percent, similar to the preceding human SARS-like bat CoV, previously animal models were used to identify the pathogenicity of SARS-CoV-2 infections. The mobile receptors of human ACE2 are identified through both severe acute respiratory syndrome coronavirus (SARS-CoV) and novel coronavirus (CoV). Plausibly, genetically modified hamsters or mice accompanied by TALEN or CRISPR could be applied to assess the pathogenesis of novel coronaviruses (CoV). SARS-CoV was reported to replicate and cause severe illness in rats (F344), where a mutation takes place at spike glycoprotein was identified in the collection study ${ }^{39}$.

Currently, by way of the stop of 2019, the WHO has been informed via the chinese language government of many patients with pneumonia of unknown cause (etiology). The pandemic coronavirus outbreak started from the Hunan seafood marketplace in Wuhan metropolis, China, and extra than 50 human beings have been unexpectedly infected. Live animals are regularly offered on the Hunan seafood market, inclusive of bats, ducks, frogs, rats, marmots and rabbits ${ }^{40}$. On $12^{\text {th }}$ January 2020, China's countrywide health commission posted greater information at the outbreak, suggesting viral pneumonia ${ }^{40}$.

Phan ${ }^{41}$ and his group reported (2020) from the collection-based totally evaluation of viral 
particles from the patients, the virus turned into diagnosed as a unique coronavirus. Additionally, the genes sequence was also provided for the viral infection analysis. To begin with, it has become recommended that people in China who have been infected with Wuhan coronavirus induced pneumonia may also have exposure to the seafood marketplace, where live animals have been traded or may have used infected animals and birds as a food source. Additionally, recent studies found that some people received less contamination inspite of no document for exposure to seafood market. These findings demonstrated that the transmission of virus from person to person, which consequently became suggested around 100 countries worldwide. The transmission of the virus from person to person occurs through close contact with an infected individual exposure to coughing, sneezing, respiration droplets or aerosols. Droplets containing viral particles can enter the human body through inhalation (lungs) and touching the nose or mouth.

\section{Treatment}

There may be no unique antiviral remedy proffered for COVID-19, and there is currently no vaccine available. The alternative treatment option is symptomatic, and oxygen supply through ventilation provides the significant remedy for patients with life threatening conditions. In cases of respiratory failure refractory to oxygen therapy, mechanical air flow could be critical, while hemodynamic assistance is crucial to coping with septic shock ${ }^{42}$.

\section{Other treatment}

Among other therapeutic interventions, systemic corticosteroids for combating viral pneumonia or acute respiratory distress syndrome (ARDS) are not recommended. Furthermore, unselective or beside the point management of antibiotics have to be averted, even though some centers suggest it. Even though no antiviral remedies were permitted, several drugs have been proposed which include lopinavir/ritonavir $(400 / 100 \mathrm{mg}$ ) (Fig. 3), chloroquine (500 mg) and hydroxychloroquine $(200 \mathrm{mg})$ for every 12 hours. Alpha-interferon ( 5 million gadgets with the aid of aerosol inhalation two times according to day) was used for treatment ${ }^{43,44}$.

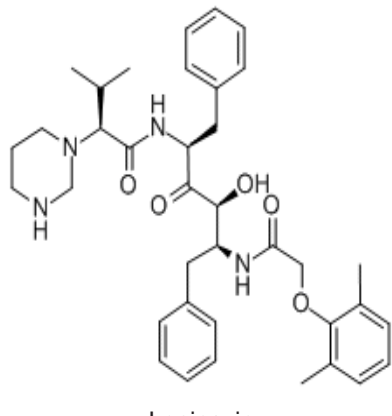

Lopinavir

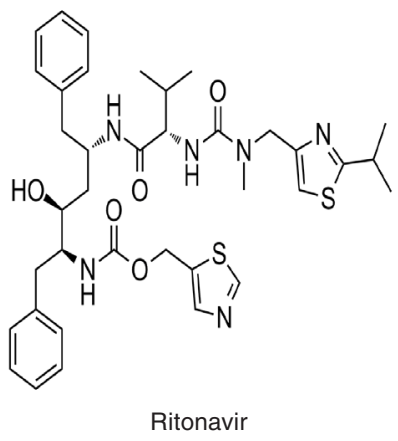

Fig. 3. Chemical structure of protease inhibitors antiviral drugs $^{30}$

Chloroquine (Fig. 4), 7-chloro-4-(4diethylamino-1-methylbutylamine)-quinoline was synthesized by 4,7-dichloroquinoline interacting with 4-diethylamino1-methylbutylamine ${ }^{45-47}$. Hydroxychloroquine (Fig.4), 7-chloro-4-[4-[ethyl(2hydroxyethyl)amino]-1-methylbutylamino]quinoline, was synthesized by a process related to that of producing chloroquine. 1-chloro-4-pentanone react with 2-ethylaminoethanol yields 4-[ethyl(2hydroxyethyl)amino]-1-methylbutylamine to the respective aminoketone, which undergoes reductive amination further it reacts with 4,7-dichlroquinoline to yield hydroxychloroquine ${ }^{48,49}$. However, chloroquine and hydroxychloroquine structure and mechanism of action was relatively similar along with a specific hydroxy moiety in one HCQ terminal. Both exist as a weak base which could alter the $\mathrm{pH}$ of acidic intracellular organels like endosomes/lysosomes, which is necessary for membrane fusion. It is recommended that both the agents could be powerful drugs against SARS-CoV-1 and SARS-CoV-25051.

\section{Heterocyclic antiviral drugs}

Previously, several heterocyclic compounds were being used to treat various viral diseases and with evidence of plausible efficacy for SARS-CoV-2, some of the compounds are being tested to treat 
COVID-19 disease through In vitro studies as well as by direct therapeutic approaches. Heterocyclic antivirals drugs includes galidesivir, darunavir and umifenovir (Fig. 5.) were used to treat HIV, influenza $A(\mathrm{H} 1 \mathrm{~N} 1)$, influenza A virus subtype (H1N5) avian flu and severe acute respiratory syndrome (SARS) which are actively practiced for assessment of SARS-CoV-2. Neuraminidase inhibitor, oseltamivir (Tamiflu) drug was commonly used to treat influenza, which has also been suggested to treat COVID-19 infections ${ }^{53}$.<smiles>CCN(CC)CCCC(C)Nc1ccnc2cc(Cl)ccc12</smiles><smiles>CCN(CCO)CCCC(C)Nc1ccnc2cc(Cl)ccc12</smiles>

Fig. 4. Chemical structure of aminoquinolones polymerase inhibitors antiviral drugs ${ }^{52,33}$

Galidesivir (Immucillins), a sequence of azasugar-C-nucleosides, exhibited efficient drug therapy for leukemia, autoimmune diseases, bacterial and viral infections ${ }^{54}$. Pyrrolidine nitrogen atom facilitates these nitrogenous bases to act as transition state analog inhibitors of certain nucleoside-processing enzymes including human purine nucleoside phosphorylase, 4 5'-methylthioadenosine nucleosidase and 5'methylthioadenosine phosphorylase ${ }^{55}$. Inhibitors possess diverse pharmacological activities due to the diverse vital functions of these enzymes on several organisms. Most significant inhibition of quorum sensing by $45^{\prime}$-methylthioadenosine nucleosidase and anticancer activity by $5^{\prime}-$ methylthioadenosine phosphorylase and purine nucleoside phosphorylase 56-58 and other effects include antiparastic and antibacterial activity ${ }^{59-61}$. Immucillin A exhibits a broad array of antiviral effect, and the blocker of RNA polymerase acts as a non- obligatory chain terminator. Currently, the drug galidesivir used under clinical trials to treat SARSCoV-2 and also to treat ebola virus infections ${ }^{62-64}$.

Umifenovir $\left(\mathrm{C}_{22} \mathrm{H}_{25} \mathrm{BrN}_{2} \mathrm{O}_{3} \mathrm{~S}\right)$, ethyl 6-bromo4-[(dimethylamino)methyl]-5-hydroxy-1-methyl-2[(phenylsulfanyl) methyl]-1H-indole-3-carboxylate) (Fig. 5), an oral antiviral drug approved in Russia in 1993 (Arbidol $($ ) ) and in China in 2006 for the prevention and therapeutic interventions of influenza $A$ and $B$ viral infections ${ }^{65}$. Earlier scientific and clinical research revealed that umifenovir could suppress replication of the SARS virus by In vitro studies ${ }^{66,67}$.<smiles>Nc1ncnc2c([C@@H]3N[C@H](CO)[C@@H](O)[C@H]3O)c[nH]c12</smiles><smiles>CCOC(=O)c1c(CSc2ccccc2)n(C)c2cc(Br)c(O)c(CN(C)C)c12</smiles><smiles>CC(C)CN(C[C@@H](O)[C@@H](Cc1ccccc1)NC(=O)O[C@@H]1CCOC1)S(=O)(=O)c1ccc(N)cc1</smiles>

Darunavir

Fig. 5. Chemical structure of heterocyclic antiviral drugs ${ }^{30,33}$

Oseltamivir phosphate $\left(\mathrm{C}_{16} \mathrm{H}_{28} \mathrm{~N}_{2} \mathrm{O}_{4}\right)$, (3R, 4R, 5S) - 4 - acetylamino-5-amino-3(1ethylpropoxy)-1-cyclohexene-1-carboxylic acid, ethyl 
ester, phosphate (1:1) is a white crystalline powder (Fig. 6). The molecular weight of oseltamivir and oseltamivir phosphate salt is 312.4 and 410.4 , respectively ${ }^{68}$. Oseltamivir, an ester prodrug that is efficiently and completely hydrolyzed into oseltamivir carboxylate (active form) by In vivo, a potent and effective inhibitor of the influenza virus neuraminidase 1 and proved to be the prominent antiviral drug presently available in the market to combat a severe influenza pandemic or epidemic outbreak ${ }^{69,70}$.<smiles>CCC(CC)O[C@H]1C=C(C(=O)O)C[C@H](N)[C@H]1NC(C)=O</smiles>

Fig. 6. Chemical structure of neuraminidase inhibitor, oseltamivir antiviral drugs ${ }^{30}$

\section{Prevention}

$\mathrm{WHO}^{5}$, and different companies provided the following current guidelines are:

1. Keep away from the direct contact with individuals affected by acute respiratory infections.

2. Wash your arms often, especially after touch with infected human beings or their surroundings.

3. Keep away from unprotected contact with livestock or wild animals.

4. Persons with acute airway infection clinical symptoms should keep distance away from cowl coughs or sneezes with disposable tissues or towels, and wipe their arms.

5. Fortify the implementation of stringent safety guidelines for the prevention and control of infections in medical drug sectors.

6. People who can be immunocompromised should restrict themselves from public activities.

The maximum effective strategy for the people should follow routinely clean their hands and use transportable hand sanitizer after engaging with possibly infected surroundings and avoid touching their nose, eyes and mouth. Medical practitioners involved in the direct care of patients should wear the personal protective equipment (PPE) consisting of N95 or FFP3 masks, eye safety (goggles or face shield), robes, gloves and gowns to protect from viral transmission ${ }^{71,72}$.

\section{CONCLUSION}

There has been an expeditious surge in research in response to the outbreak of COVID-19. In this early phase, published work mainly investigated the epidemiology, causes, clinical presentation and diagnosis, as well as the novel coronavirus prevention and controls. While these researches are significant to controlling the current public emergent situation, there is a need for more high-quality investigation to provide accurate and reliable strategies to monitor this sort of short- and long-term public health emergency. The potential for a human $\mathrm{CoV}$ pandemic remains a significant concern to international health security. Though, people around the world have not attained sufficient knowledge in preceding fights with SARS and MERS. Due to COVID-19 outbreak, SARS-CoV-2 received global attention as a potential pathogen in respiratory infections. In order to offer a concise overview to public health officials and future readers around the world, we have outlined the latest interpretation of COVID-19 and presented the current status of implementation of the interventions in this review.

\section{ACKNOWLEDGEMENT}

The authors gratefully acknowledge the Management of Sathyabama Institute of Science and Technology, Chennai and the Professor K. R. Venakatesan, Principal, Sri Sankara Arts and Science College, Kanchipuram, Tamilnadu, India for their help and cooperation.

\section{Conflicts of interest}

We here by certify that there are no conflicts of interest.

\section{REFERENCES}

1. Huang, C.; Wang, Y.; Li, X.; Ren, L.; Zhao, J.; Hu, Y.; Zhang, L.; Fan, G.; Xu, J.; Gu, X.; Cheng, Z. Lancet., 2020, 395, 497-506.

2. International Committee on Taxonomy of Virus. https://talk.ictvonline.org/2020.

3. Notice of the National Health Commission of the People's Republic of China http:// www.nhc.gov.cn/yzygj/s7653p/202002/ 33393aa53d984ccdb1053a52b6bef810. shtml., 2020. 
4. Zhong, N.S.; Zheng, B.J.; Li, Y.M.; Poon, L.L.M.; Xie, Z.H.; Chan, K.H.; Li, P.H.; Tan, S.Y.; Chang, Q.; Xie, J.P.; Liu, X.Q. The Lancet., 2003, 362, 1353-1358.

5. World Health Organization. https://www.who. int/news-room/q-a-detail/q-a-coronaviruses., 2020.

6. Lu, G.;Wang, Q.; Gao, G.F. Trends Microbiol., 2015, 23, 468-78.

7. World Health Organization. http://www.who. int/csr/sars/country/table2004_04_21/en/ index.html., 2003.

8. World Health Organization. http://www. who.int/csr/disease/coronavirus_infections/ riskassessment-august-2018.pdf.ua=1., 2018.

9. Huang, C.; Wang, Y.; Li, X.; Ren, L.; Zhao, J.; Hu, Y.; Zhang, L.; Fan, G.; Xu, J.; Gu, X.; Cheng, Z. The Lancet, 2020, 395, 497-506.

10. Xiong, C.; Jiang, L.; Chen, Y.; Jiang, Q. Biorxiv., 2020.

11. Yu, W.B.; Tang, G.D.; Zhang, L.; Corlett, R.T. Zool. Res., 2020, 41, 247.

12. Zhao, L.; Jha, B.K.;Wu, A.; Elliott, R.; Ziebuhr, J.; Gorbalenya, A.E.; Silverman, R.H.; Weiss, S.R. Cell Host Microbe., 2012, 11, 607-616.

13. Lei, J.; Kusov, Y.; Hilgenfeld, R. Antiviral Res., 2018, 149, 58-74.

14. Perlman, S.; Netland, J. Nat. Rev. Microbiol., 2009, 7, 439-450.

15. Li, Y.H.; Li, J.; Liu, X.E.;Wang, L.; Li, T.; Zhou, Y.H.; Zhuang, H. J. Virol. Methods., 2005, 130, 45-50.

16. Corman, V.M.; Muth, D.; Niemeyer, D.; Drosten, C. Adv. Virus Res., 2018, 100, 163-188.

17. Lam, T.T.Y.; Shum, M.H.H.;Zhu, H.C.; Tong, Y.G.; Ni, X.B.; Liao, Y.S.; Wei, W.; Cheung, W.Y.M.; Li, W.J.; Li, L.F.; Leung, G.M. BioRxiv., 2020.

18. Jiang, F.; Deng, L.; Zhang, L.; Cai, Y.; Cheung, C.W.; Xia, Z. J. Gen.lintern. Med., 2020, 1-5.

19. Chen, N.; Zhou, M.; Dong, X.; Qu, J.; Gong, F.; Han, Y.; Qiu, Y.; Wang, J.; Liu, Y.; Wei, Y.; Yu, T. Lancet., 2020, 395, 507-513.

20. Wang, D.; Hu, B.; Hu, C.; Zhu, F.; Liu, X.; Zhang, J.; Wang, B.; Xiang, H.; Cheng, Z.; Xiong, Y.; Zhao, Y. JAMA., 2020, 323, 1061-1069.

21. Xu, X.W.;Wu, X.X.; Jiang, X.G.; Xu, K.J.;Ying, L.J.; Ma, C.L.; Li, S.B.; Wang, H.Y.; Zhang, S.; Gao, H.N.; Sheng, J.F. BMJ., 2020, 368.

22. Guan, W.J.; Ni, Z.Y.; Hu, Y.; Liang, W.H.; Ou, C.Q.; He, J.X.; Liu, L.; Shan, H.; Lei, C.L.; Hui, D.S.; Du, B. MedRxiv., 2020.
23. Zhang, J.J.; Dong, X.; Cao, Y.Y.; Yuan, Y.D.; Yang, Y.B.; Yan, Y.Q.; Akdis, C.A.; Gao, Y.D. Allergy., 2020.

24. De Wit, E.; Van Doremalen, N.; Falzarano, D.; Munster, V.J. Nat. Rev. Microbiol., 2016, 14, 523.

25. Zumla, A.; Hui, D.S.; Perlman, S. Lancet., 2015, 386, 995-1007.

26. Al-Omari, A.; Rabaan, A.A.; Salih, S.; AlTawfiq, J.A.; Memish, Z.A. Diagn. Microbiol. Infect. Dis., 2019, 93, 265-285.

27. Yeung, M.L.; Yao, Y.; Jia, L.; Chan, J.F.; Chan, K.H.; Cheung, K.F.; Chen, H.; Poon, V.K.; Tsang, A.K.; To, K.K.; Yiu, M.K. Nat. Microbiol., 2016, 1, 1-8.

28. Wang, M.; Cao, R.; Zhang, L.; Yang, X.; Liu, J.; Xu, M.; Shi, Z.; Hu, Z.; Zhong, W.; Xiao, G. Cell Res., 2020, 30, 269-271.

29. Mulangu, S.; Dodd, L.E.; Davey Jr, R.T.; Tshiani Mbaya, O.; Proschan, M.; Mukadi, D.; Lusakibanza Manzo, M.; Nzolo, D.; Tshomba Oloma, A.; Ibanda, A.; Ali, R. Engl. J. Med., 2019, 381, 2293-2303.

30. Shah, B.; Modi, P.; Sagar, S.R. Life Sci., 2020, 117, 652.

31. Agostini, M.L.; Andres, E.L.; Sims, A.C.; Graham, R.L.; Sheahan, T.P.; Lu, X.; Smith, E.C.; Case, J.B.; Feng, J.Y.; Jordan, R.; Ray, A.S. MBio., 2018, 9(2).

32. National Health Commission. http://en.nhc. gov.cn/index.html., 2020.

33. Costanzo, M., De Giglio, M.A.R. and Roviello, G.N. Curr. Med. Chem., 2020.

34. China Food and Drug Administration. http:// www.nmpa.gov.cn/WS04/CL2056/ 374264. html., 2020.

35. Wang, Z.; Chen, X.; Lu, Y.; Chen, F.; Zhang, W. BioSci. Trends., 2020.

36. Zhang, K.; Deng, R.; Teng, X.; Li, Y.; Sun, Y.; Ren, X.; Li, J. J. Am. Chem. Soc., 2018. 140, 11293-11301.

37. Gretebeck, L.M.; Subbarao, K. Cur. Opin. Virol., 2015, 13, 123-129.

38. Cockrell, A.S.; Peck, K.M.; Yount, B.L.; Agnihothram, S.S.; Scobey, T.; Curnes, N.R.; Baric, R.S.; Heise, M.T. J. Virol., 2014, 88, 5195-5199.

39. Nagata, N.; Iwata, N.; Hasegawa, H.; Fukushi, S.; Yokoyama, M.; Harashima, A.; Sato, Y.; Saijo, M.; Morikawa, S.; Sata, T. J.Virol., 2007, 81, 1848-1857. 
40. Wang, C.; Horby, P.W.; Hayden, F.G.; Gao, G.F. The Lancet., 2020, 395, 470-473.

41. Phan, L.T.; Nguyen, T.V.; Luong, Q.C.; Nguyen, T.V.; Nguyen, H.T.; Le, H.Q.; Nguyen, T.T.; Cao, T.M.; Pham, Q.D. Engl. J. Med., 2020, 382, 872-874.

42. Cascella, M.; Rajnik, M.; Cuomo, A.; Dulebohn, S.C.; Di Napoli, R. StatPearls Publishing., 2020.

43. Zhang, Y.; Xu, Q.; Sun, Z.; Zhou, L. Pharmacol. Res., 2020, 104, 854.

44. Singh, A.K.; Singh, A.; Shaikh, A.; Singh, R.; Misra, A. Diabetes Metab. Syndr., 2020.

45. Andersag, H.; Breitner, S.; Jung, H. U.S. Pat., 2.233.970, 1941.

46. Andersag, H.; Breitner, S.; Jung, H. Ger. Pat., 683.692, 1937.

47. Drake, N.L.; Creech, H.J.; Garman, J.A.; Haywood, S.T.; Peck, R.M.; Van Hook, J.O.; Walton, E. J. Am. Chem. Soc., 1946, 68, 1214.

48. Surrey, A.R. U.S. Pat., 2.546.658, 1951.

49. Surrey, A.R.; Hammer, H.F. J. Am. Chem. Soc., 1950, 72, 1814.

50. Colson, P.; Rolain, J.M.; Lagier, J.C.; Brouqui, P.; Raoult, D. Int. J. Antimicrob. Agents., 2020, 4, 105932.

51. Biot, C.; Daher, W.; Chavain, N.; Fandeur, T.; Khalife, J.; Dive, D. J. Med. Chem., 2006, 49, 2845-2849.

52. Chhikara, B.S.; Rathi, B.; Singh, J.; Poonam, F.N.U. Chem. Biol. Lett., 2020, 7, 63-72.

53. Li, H.; Wang, Y.M.; Xu, J.Y.; Cao, B. Chinese J. Tuberculosis Respiratory Diseases., 2020, 43.

54. Gary, B. E.; Vern, L. S.; Peter, C. T. Curr. Med. Chem., 2015, 22, 3897-3909.

55. Evans, G. B.; Furneaux, R. H.; Schramm, V. L.; Singh, V.; Tyler, P. C. J. Med. Chem., 2004, 47, 3275-3281.

56. Gutierrez, J. A.; Crowder, T.; Rinaldo-Matthis, A.; Ho, M. C.; Almo, S. C.; Schramm, V. L. Nat. Chem. Biol., 2009, 5, 251-257.

57. Basu, I.; Locker, J.; Cassera, M. B.; Belbin, T. J.; Merino, E. F.; Dong, X.; Hemeon, I.; Evans, G. B.; Guha, C.; Schramm, V. L. J. Biol. Chem., 2011, 286, 4902-4911.

58. Ho, M. C.; Shi, W.; Rinaldo-Matthis, A.; Tyler, P. C.; Evans, G. B.; Clinch, K.; Almo, S. C.; Schramm, V. L. Proc. Natl. Acad. Sci., 2010,
107, 4805-4812.

59. Freitas, E. O.; Nico, D.; Guan, R.; MeyerFernandes, J. R.; Clinch, K.; Evans, G. B.; Tyler, P. C.; Schramm, V. L.; Palatnik-de-Sousa, C. B. PLoS One., 2015, 10, e0124183.

60. Wang, S.; Haapalainen, A. M.; Yan, F.; Du, Q.; Tyler, P. C.; Evans, G. B.; RinaldoMatthis, A.; Brown, R. L.; Norris, G. E.; Almo, S. C.; Schramm, V. L. Biochemistry., 2012, 51, 6892-6894.

61. Wang, S.; Cameron, S. A.; Clinch, K.; Evans, G. B.; Wu, Z.; Schramm, V. L.; Tyler, P. C. J. Am.Chem. Soc., 2015, 137, 14275-14280.

62. Warren, T. K.; Wells, J.; Panchal, R. G.; Stuthman, K. S.; Garza, N. L.; Van Tongeren, S. A.; Dong, L.; Retterer, C. J.; Eaton, B. P.; Pegoraro, G.; Honnold, S.; Bantia, S.; Kotian, P.; Chen, X.; Taubenheim, B. R.; Welch, L. S.; Minning, D. M.; Babu, Y. S.; Sheridan, W. P.; Bavari, S. Nature., 2014, 508, 402-405.

63. Taylor, R.; Kotian, P.; Warren, T.; Panchal, R.; Bavari, S.; Julander, J.; Dobo, S.; Rose, A.; El-Kattan, Y.; Taubenheim, B.; Babu, Y.; Sheridan, W. P. J. Infect. Public Health., 2016, 9, 220-226.

64. Julander, J. G.; Bantia, S.; Taubenheim, B. R.; Minning, D. M.; Kotian, P.; Morrey, J. D.; Smee, D. F.; Sheridan, W. P.; Babu, Y. S. Antimicrob. Agents Chemother., 2014, 58, 6607-6614.

65. Proskurnina, E.V.; Izmailov, D.Y.; Sozarukova, M.M.; Zhuravleva, T.A.; Leneva, I.A.; Poromov, A.A. Molecules., 2020, 25.

66. Khamitov, R.A.; Loginova, S.; Shchukina, V.N.; Borisevich, S.V.; Maksimov, V.A.; Shuster, A.M. Vopr. Virusol., 2008, 53, 9-13.

67. Lu, H. Biosci. Trends., 2020, 14, 69-71.

68. International Pharmacopoeia, World health organization, $4^{\text {th }}$ Edition., 2008.

69. Mayor, S. BMJ., 2006, 332, 196.

70. Jefferson, T.; Demicheli, V.; Rivetti, D.; Jones, M.; Di Pietrantonj, C.; Rivetti, A. Lancet., 2006, 367, 303-313.

71. Ippolito, M.; Vitale, F.; Accurso, G.; lozzo, P.; Gregoretti, C.; Giarratano, A.; Cortegiani, A. Pulmonology., 2020.

72. Hirschmann, M.T.; Hart, A.; Henckel, J.; Sadoghi, P.; Seil, R.; Mouton, C. Knee Surg. Sports Traumatol. Arthrosc., 2020. 